\title{
Penegakan hukum terhadap korporasi sebagai pelaku tindak pidana lingkungan hidup di wilayah hukum Sidoarjo
}

\section{Law enforcement of corporation as a performance of living environmental criminal actions in the Sidoarjo legal region}

\author{
R. Dwi Kennardi Dewanto P \\ Program Studi Magister Kajian Ilmu Kepolisian, Sekolah Pascasarjana Universitas Airlangga \\ Surabaya, 60286, Jawa Timur, Indonesia \\ E-mail: r.dwi.kennardi.dewanto-2015@pasca.unair.ac.id
}

\begin{abstract}
Abstrak
Penegakan hukum lingkungan dilakukan melalui upaya represif, yaitu melalui saluran penegakan hukum pidana untuk memulai penyelidikan keputusan pengadilan. Kasus yang dibahas melibatkan korporasi, sehingga sesuai dengan Pasal 116 ayat (1) dan (2) UU No 32 dari 2009 sanksi yang dikenakan pada badan usaha atau orang yang memberikan perintah untuk melakukan kejahatan atau orang yang bertindak sebagai pemimpin kegiatan dalam kejahatan. Metode analisis data yang digunakan dalam penelitian ini adalah analisis data kualitatif. Hasil penelitian ini menunjukkan berbagai kendala untuk penegakan hukum terhadap perusahaan sebagai pelaku kejahatan lingkungan di wilayah hukum Sidoarjo yang mengakibatkan ketidakefektifan penegakan hukum lingkungan, antara lain, Fasilitas hukum, aparat penegak hukum, Fasilitas dan fasilitas, izin, sistem analisis dampak lingkungan (AMDAL), dan kurangnya partisipasi masyarakat. Upaya yang perlu dilakukan untuk mengatasi kendala penegakan hukum terhadap kejahatan korporasi terhadap lingkungan di Sidoarjo meliputi: meningkatkan jumlah aparat penegak hukum, peningkatan pengawasan setelah pemberian lisensi, peningkatan fungsi AMDAL sebagai alat penegakan hukum lingkungan, dan memberikan pelatihan/pelatihan kepada aparat penegak hukum yang berkonsentrasi pada hukum lingkungan.
\end{abstract}

Kata kunci: lingkungan; hukum pidana; kontrol sosial; koorporasi; penegakan hukum

\begin{abstract}
Environmental law enforcement is conducted through a repressive effort, i.e. through criminal law enforcement channels to initiate a court decision investigation. The cases discussed involving corporations, so in accordance with article 116 paragraph (1) and (2) of LAW No. 32 of 2009 sanctions imposed on a business entity or person giving orders to commit crimes or persons acting as leaders of activities in crime. The data analysis methods used in this study are qualitative data analysis. The results of this study showed various constraints for law enforcement against the company as an environmental crime perpetrator in Sidoarjo which resulted in the ineffectiveness of environmental law enforcement, among others, legal facilities, law enforcement officers, facilities and facilities, permits, environmental impact Analysis System (AMDAL), and lack of community participation. Efforts that need to be done to overcome law enforcement constraints against corporate crimes against the environment in Sidoarjo include: increasing the number of law enforcement officers; improve supervision after licensing; improving AMDAL function as an environmental law enforcement tool; and provide training/training to law enforcement officials who concentrate on environmental law.
\end{abstract}

Keywords: environment; criminal law; social control; coorporation; law enforcement

\section{Pendahuluan}

Pada tahun 2014, Badan Lingkungan Hidup (BLH) Kab. Sidoarjo mendeteksi ada 57 perusahaan di Sidoarjo terindikasi mencemari lingkungan. Dari sekitar 57 kasus pencemaran yang ditangani BLH, beberapa diantaranya sudah diperingatkan keras. Bahkan, berdasarkan proper yang dilakukan Kementerian Lingkungan Hidup, beberapa diantaranya diberi raport merah. Kepala BLH Kab. Sidoarjo Siswojo 57 kasus pencemaran lingkungan itu terjadi selama tahun 2014. Selain itu, pihaknya juga mengawasi perusahaan, restoran, home industri maupun rumah tangga agar jangan sampai mencemari lingkungan. Saat ini, yang menjadi pengawasan SKPR (Kami membentuk Status Kinerja Pengelolaan Lingkungan) sebanyak 27 perusahaan. Perusahaan itu terindikasi mencemari lingkungan 
berdasarkan hasil uji sampel yang diambil BLH. Selain itu, ada 30 perusahaan itu sudah masuk pengawasan Kementerian Lingkungan Hidup.

Terdapat beberapa kasus pencemaran lingkungan yang sudah diproses hukum di wilayah hukum Sidoarjo. Seperti kasus pada Eddy Iswantoro selaku pemilik UD Mulya yang bergerak di bidang perdagangan kaleng, alumunium, besi, bertanggung jawab terhadap seluruh operasional usahanya. Kasus ini dimuat dalam Putusan Nomor 673/PID.Sus/2015/PN SDA. Dalam menjalankan usahanya, melakukan peleburan kaleng alumunium, panci, wajan dan kaleng minuman bekas, terdakwa memperoleh bahan baku dari pengepul besi/logam bekas / rosokan. Sisa dari proses peleburan alumunium tersebut berupa cairan timah, lalu tempat peleburan diberi tekanan panas, sehingga cairan timah keluar berupa butiran hitam, kemudian diayak dan dilakukan peleburan kembali hingga yang tersisa berupa abu/serbuk (limbah) yang tidak ada kandungan timahnya.

Dalam sehari alumunium bekas yang dilebur terdakwa sekitar 800 (delapan ratus) kilogram s/d 1.000 (seribu) kilogram, dengan proses peleburan mulai jam 08.00 wib s/d 17.00 wib hari minggu libur. Abu sisa peleburan alumunium (limbah) tersebut oleh terdakwa dimasukan dalam sak plastik ukuran 50 (lima puluh) kilogram dan ditaruh dilantai dalam lokasi gudang UD Mulya, lalu setelah terkumpul sekitar 5 (lima) s/d 6 (enam) ton, limbah tersebut oleh terdakwa dijual. Ternyata ijin yang dimiliki oleh terdakwa adalah Usaha Dagang bukan proses peleburan alumunium, dan dalam proses tersebut terdakwa juga tidak memiliki sistem pengolahan limbah. Setelah dilakukan uji Laboratorium atas limbah abu/serbuk yang dihasil dari proses peleburan alumunium tersebut adalah limbah B3 (Bahan Berbahaya dan Beracun) sesuai dengan Sertifikat Hasil Pengujian TCLP Limbah Padat No. 660/882.1/2015 tanggal 22 Juli 2015. Dalam Kasus ini, majelis hakim telah memutuskan: Menyatakan terdakwa Eddy Iswanto tersebut di atas terbukti secara sah dan meyakinkan bersalah melakukan tindak pidana Lingkungan Hidup; Menghukum Terdakwa dengan pidana penjara selama 1 (satu) tahun dan denda Rp1.000.000.000,00 (satu milyar rupiah), dengan ketentuan apabila denda tersebut tidak dibayar, diganti dengan kurungan selama 1 (satu) bulan.

Kasus lainnya terjadi pada Udi Hartono yang termuat dalam putusan Putusan Nomor 928 K/PID.SUS.LH/2016. Putusan Pengadilan Negeri Sidoarjo dalam Putusan Nomor 274/Pid.Sus/2015 /PN.SDA telah memutuskan: Menyatakan terdakwa Udi Hartono terbukti secara sah dan meyakinkan bersalah melakukan tindak pidana "Menyuruh Melakukan Pengelolaan Limbah B3 Tanpa Ijin; Menjatuhkan pidana kepada Terdakwa tersebut di atas dengan pidana penjara selama 1 (satu) tahun dan denda sebesar Rp1.000.000.000,00 (satu miliar rupiah), dengan ketentuan apabila denda tersebut tidak dibayar maka akan diganti dengan pidana kurungan selama 1 (satu) bulan; barang bukti dikembalikan kepada terpidana; dan membebankan biaya perkara kepada Terdakwa sebesar Rp2.500,00 (dua ribu lima ratus rupiah).Putusan ini kemudian dikuatkan lagi dengan Putusan Pengadilan Tinggi Surabaya Nomor 435/PID.SUS/2015/PT.BY., tanggal 22 September 2015. Terdakwa juga telah mengajukan Kasasi, akan tetapi Majelis Hakim mengambil keputusan menolak permohonan kasasi dari Pemohon Kasasi/Terdakwa UDI HARTONO tersebut; Membebankan kepada Terdakwa untuk membayar biaya perkara pada tingkat Kasasi sebesar Rp 2.500,00 (dua ribu lima ratus rupiah).

Dua kasus di atas adalah contoh kasus pencemaran lingkungan yang telah diproses secara hukum di wilayah hukum Sidoarjo. Banyak kasus pencemaran lain yang dalam proses penyelesain, baik penyelesaian di lingkungan peradilan maupun peyelesaian di luar pengadilan. Terhadap kasus pencemaran lingkungan memang perlu diambil tindakan karena pencemaran lingkungan ini secara langsung berdampak pada kehidupan manusia dan lingkungan manusia. Selain contoh diatas, terdapat beberapa kasus lain seperti kejahatan lingkungan PT Lapindo Brantas (Rosman \& Isa, 2014). Peningkatan perlindungan terhadap lingkungan adalah fokus banyak negara pada dekade-dekade terakhir abad kedua puluh (Shover \& Routhe, 2005; Barrett \& White, 2017; Cho, 2000; Greife et al, 2015; Cohen, 1992).

Berdasarkan uraian yang telah disampaikan pada bagian latar belakang, maka rumusan masalah yang dapat diajukan dalam penelitian ini adalah: a) Bagaimanakah penegakan hukum terhadap kejahatan 
korporasi dalam tindak pidana lingkungan hidup di Sidoarjo? b) Kendala apakah yang dihadapi dalam penegakan hukum terhadap kejahatan korporasi dalam tindak pidana lingkungan hidup di wilayah hukum Sidoarjo?

\section{Metode Penelitian}

Penelitian ini menggunakan jenis penelitian hukum empiris yang bertumpu pada pendekatan sosio legal. Analisa data yang digunakan dalam penelitian ini adalah analisis data kualitatif (Moleong, 2012). Setelah data terkumpul, dilakukan reduksi dan ketegorisasi data. Data dianalisis dan didiskusikan dengan teori dan studi-studi yang relevan dengan topik yang dikaji.

\section{Hasil dan Pembahasan}

Penegakan hukum terhadap korporasi sebagai pelaku tindak pidana lingkungan hidup di Sidoarjo Sebelum menjelaskan mengenai bagaimana penegakan hukum korporasi dalam tindak pidana lingkungan hidup di Sidoarjo, maka akan penulis gambarkan terselibih dahulu contoh kasus sebagai berikut:

\section{P U T U S A N Nomor 673/PID.Sus/2015/PN SDA}

\begin{tabular}{ll}
\hline Identitas terdakwa ini adalah: \\
Nama lengkap & : Eddy Iswantoro; \\
Tempat lahir & : Sidoarjo; \\
Umur/Tanggal lahir & $:$ 49 Tahun/28 Mei 1966; \\
Jenis Kelamin & : Laki-laki; \\
Kebangsaan & : Indonesia; \\
Tempat tinggal & $:$ Desa Terung Wetan RT-05 RW-02 Kec. Krian, Kab. Sidoarjo; \\
Agama & $:$ Islam; \\
Pekerjaan & $:$ Swasta
\end{tabular}

Kronologis dari kasus ini adalah terdakwa Eddy Iswantoro, selaku pemilik UD mulya, pada hari dan tanggal yang tidak ditentukan dengan hasil antara tahun $2013 \mathrm{~s} / \mathrm{d}$ 2015, atau setidak-tidaknya disekitar waktu itu dalam tahun 2130 s/d 2015 bertempat di Desa Terung Wetan RT-05 RW-02 Kec. Krian Kab. Sidoarjo, atau setidak- tidaknya disuatu tempat yang masih termasuk dalam dalam hukum Pengadilan Negeri Sidoarjo, berwewenang mengadili perkara menghasilkan limbah B3 dan tidak melakukan pengelolaan.

Sebagaimana maksud Pasal 59 Ayat (1) (setiap orang yang menghasilkan limbah B3 wajib melakukan penggelolaan lima B3), yang dilakukan terdakwa dengan cara sebagai berkut: 1) Terdakwa selaku pemilik UD mulya yang bergerak di bidang perdagangan kaleng, aluminium, besi, bertanggung jawab terhadap seluruh operasional usahanya; 2) Dalam menjalankan usahannya, melakukan peleburan kaleng aluminium, panci, wajan dan kaleng minuman bekas, terdakwa memperoleh bahan baku dari pengepul besi/logam bekas/rosokan; 3) Setelah bahan baku tersebut terkumpul lalu dilakukan proses peleburan yang awalnya aluminium bekas ditempatkan di kowi (tempat peleburan), kemudian dilakukan pemanasan dengan menggunakan bahan bakar kayu sampai aluminium cair, lalu aluminium yang sudah cair dicetak berbentuk kotak ukuran 4 - 5 kilogram, selanjutnya dipasarkan; 4) Sisa dari proses aluminium tersebut berupa cairan timah, lalu, tempat peleburan diberi tekanan panas, sehingga cairan timah keluar berupa butiran hitam, kemudian diayak dan dilakukan peleburan kembali hingga yang tersisa berupa abu/serbuk (limbah yang tidak ada kandungan timahnya; 5) Dalam sehari aluminium bekas yang dilebur terdakwa sekitar 800 (delapan ratus) kilogram s/d 1.000 (seribu) kilogram, dengan proses peleburan mulai jam 08.00 wib s/d 17.00 wib hari minggu libur. Bahwa abu sisa peleburan alumium (limbah) tersebut oleh terdakwa dimasukkan dalam sak plastik ukuran 50 (lima puluh) kilogram dan ditaruh dilantai dalam lokasi gudang UD Mulya, lalu setelah terkumpul sekitar 5 (lima) s/d 7 (enam) limbah tersebut oleh terdakwa dijual; 6) Ternyata ijin yang dimiliki oleh terdakwa adalah Usaha Dagang bukan proses peleburan aluminium, dan dalam proses tersebut 
terdakwa juga tidak memiki sistem pengolahan limbah; 7) Setelah dilakukan uji laboratorium atas limbah abu/serbuk yang dihasil dari proses peleburan aluminium tersebut limbah B3 (Bahan Berbahaya dan beracun) sesuai dengan Sertifikat Hasil Pengujian TCLP Limbah Padat No. 660/882.1/2015 tanggal 2 Juli 2015, yang dibuat dan ditanda tangani atas kekuatan sumpah jabatan oleh Wahyu Nugroho selaku Manajer Teknis UPT Lab. Uji Kualitas Lingkungan, Mengetahui Ir. Sunarta, MM selaku kepala UPT Lab. Uji Kualitas Lingkungan, Badan Lingkungan Hidup Propinsi Jawa Timur, yang menyimpulkan terdapat 2) parameter yang melebihi baku mutu yang diterapkan sesuai PP 101 Tahun 2014 tentang pengelolaan Limbah Bahan Berbahaya dan Beracun pada lampiran IV, yaitu parameter Seng $(\mathrm{Zn})$ dan Timbal $(\mathrm{Pb})$ bahwa atas limbah yang kulitasnya melebihi baku mutu yang telah ditetapkan kemudian dibuang ke media lingkungan, akan mengakibatkan pencemaran lingkungan. Perbuaatan terdakwa melanggar ketentuan sebagaiman diatur dan diancam pidana dalam Pasal 103 jo 59 Ayat (1) UU RI Nomor 32 Tahun 2009 tentang Perlindungan dan Penglolaan Lingkungan Hidup.

Terhadap kasus tersebut, maka Jaksa Penuntut Umum mengajukan tuntutannya sebagai berikut: (1) Menyatakan terdakwa Eddy Iswantoro, secara sah dan meyakinkan terbukti bersalah melakukan Tindak Pidana Lingkungan Hidup sebagaimana dalam surat dakwaan melanggar Pasal 103 jo 59 Ayat (1) UU RI Nomor 32 Tahun 2009 tentang Perlindungan dan Pengelolaan Lingkungan Hidup; (2) Menghukum terdakwa Eddy Iswantoro dengan pidana penjara selama 2 (dua) Tahun dan denda sebesar Rp. 1.000.000.000,00 (satu miliar rupiah) Subsidair 3 (tiga) bulan kurungan; (3) Menyatakan barang bukti berupa 1 (satu) sak plastik limbah B3 dimusnahkan; (4) Menetapkan terdakwa dibebani membayar biaya perkara sebesar Rp. 2.500,00 (dua ribu lima ratus rupiah). Aturan ini tertera dalam buku milik Arifin (2012) yang membahas tentang Hukum Perlindungan dan Pengelolaan Lingkungan Hidup di Indonesia.

Setelah mendengar permohonan Terdakwa yang pada pokoknya Terdakwa mohon diberikan keringanan hukuman dengan alasan Terdakwa mempunyai tanggung jawab keluarga, Terdakwa menyesal dan tidak akan mengulangi lagi perbuatannya. Meskipun terdakwa telah mengajukan permohonan keriganan hukuman, jaksa penuntut umum tetap pada tuntutannya. Jaksa pentunt umum tetap pada tuntutannya dan juga mengajukan saksi- saksi, yaitu Roni Hadianto, Rohmat Ifantri Firdaus, Kujaini, Nusfa Muzdalifah.

Terdakwa di persidangan telah memberikan keterangan yang pada pokoknya sebagai berikut: 1) Benar pernah datang ke tempat terdakwa 3 (tiga) orang dari Polres Sidoarjo dan menanyakan kerja apa dan siapa yang punya; 2) Benar Terdakwa telah melakukan kegiatan peleburan aluminium yang diperoleh dari pengepul barang bekas yang mengandung aluminium dengan cara membakar barang bekas mengandung aluminium sampai mendidih yang kemudian dicetak menjadi aluminium batangan; 3) Sisa hasil peleburan barang bekas mengandung aluminium adalah limbah berupa serbuk/abu berwarna hitam yang oleh terdakwa dimasukkan ke dalam zak plastic ukuran $50 \mathrm{~kg}$ kemudian diletakkan di dekat tempat peleburan; 4) Dalam satu hari peleburan bisa menghasilkan limbah serbuk /abu sekitar $100 \mathrm{~kg}$; 5) Limbah yang masih mengandung timah berupa serbuk dibeli oleh orang jombang yang katanya dilebur lagi; 6) Terdakwa tidak mempunyai ijin karena tidak tahu dan tidak tahu bahwa limbah yang dihasilkan adalah termasuk limbah B3 yang dapat mencemarkan lingkungan; 7) Terdakwa merasa menyesal dan berjanji tidak akan mengulangi lagi perbuatannya; 8) Terdakwa mempunyai tanggungan keluarga, seorang istri dan 2 (dua) anak.

Penuntut Umum mengajukan barang bukti. Selanjutnya Majelis Hakim akan mempertimbangkan apakah berdasarkan fakta-fakta hukum tersebut diatas, terdakwa dapat dinyatakan telah melakukan tindak pidana yang didakwakan kepadanya. Terdakwa telah didakwa oleh Penuntut Umum dengan dakwaan tunggal sebagaimana diatur dalam Pasal 103 jo. Pasal 59 ayat (1) undang-undang nomor 32 Tahun 2009, yang unsur-unsurnya adalah sebagai berikut: a) Setiap orang; b) Menghasilkan limbah B3; c) Wajib melakukan pengelolaan Limbah.

Dalam ketentuan Pasal 103 Undang-Undang No. 23 Tahun 2009 secara komulatif menentukan pula pidana denda, sehingga perlu majelis menghukum pula kepada Terdakwa pidana denda yang besarnya 
akan ditentukan dalam amar putusan dibawah ini Apabila pidana denda tidak dibayar maka dapat diganti dengan pidana kurungan yang lamanya akan ditentukan dalam amar putusan dibawah ini.

Oleh karena maksud dan tujuan pemidanaan bukan semata-mata sebagai pembalasan dendam kepada terdakwa, melainkan juga untuk mendidik terdakwa agar tidak mengulangi lagi perbuatannya dan melakukan hal-hal yang memang disyaratkan oleh peraturan perundang-undangan (Hamzah, 2001; Arief, 2002), maka selain dengan memperlihatkan hal-hal yang memberatkan dan hal-hal yang meringankan. Pengadilan menganggap tepat dan adil apabila kepada Terdakwa dijatuhi pidana bersyarat sebagaimana ditentukan dalam Pasal 14 (a) Kitab Undang- undang Hukum Pidana seperti yang akan disebutkan dalam amar putusan dibawah ini, 1) Hal yang menyangkut dengan pidana denda, agar pelaksanaan pidana denda tersebut sejalan dengan maksud dan tujuan dari pemindanaan bersyarat, maka Majelis akan menetapkan kapan pelaksanaan pidana denda dapat dilaksanakan yang rumusannya akan ditentukan dalam amar putusan dibawah ini; 2) Oleh karena itu terdakwa tidak ditahan dan menurut pendapat Majelis hakim tidak cukup alasan untuk menahan, maka Terdakwa tidak ditahan; 3) Terhadap barang bukti yang disita secara sah dan diajukan di persidangan oleh karena sebagian dari barang bukti sudah dimusnahkan dan hanya disasakan 1 (satu) zak maka untuk selanjutnya dipertimbangkan sebagai berikut: a) Barang bukti berupa serbuk/abu sisa peleburan aluminium (limbah B3) yang telah disita, karena berpotensi dapat mencemarkan lingkungan, dan membahayakan maka wajar apabila dirampas untuk kemudian dimusnahkan; b) Oleh karena Terdakwa dijatuhi pidana maka kepada Terdakwa harus dibebani pula untuk membayar biaya perkara; c) Memperhatikan, Pasal-pasal dalam KUHAP, Pasal 103, Pasal 59 Undang-undang no. 32 Tahun 2009 serta peraturan perundang-undangan lain yang bersangkutan.

Mengadili: 1) Menyatakan terdakwa Eddy Iswanto tersebut di atas terbukti secara sah dan meyakinkan bersalah melakukan tindak Pidana Lingkungan Hidup; 2) Menghukum Terdakwa dengan pidana penjara selama 1 (satu) tahun dan denda Rp.1.000.000.000,- (satu miliar rupiah), dengan ketentuan apabila denda tersebut tidak dibayar, diganti dengan kurungan selama 1 (satu) bulan; 3) Menetapkan hukuman penjara dan denda tersebut tidak usah dijalani kecuali jika dikemudian hari ada putusan hakim yang menentukan lain, disebabkan karena terpidana sebelum masa percobaan selama 1 (satu) tahun berakhir; 4) Mentapkan barang bukti berupa 1 (satu) zak plastik limbah B3 dirampas untuk dimusnahkan; 5) Membebankan kepada Terdakwa mambayar biaya perkara sebesar Rp. 2.500,00 (dua ribu lima ratus rupiah).

Berdasarkan uraian di atas dapat dilihat bahwa kasus pencemaran lingkungan yang diproses hukum sampai ke tahapan pengadilan adalah pencemaran yang melibatkan limbah B3. Penegakan hukum dilakukan adalah penegakan hukum pidana (Arief, 2002). Penegakan Hukum Pidana merupakan Ultimum remedium, dimana tuntutan pidana merupakan akhir mata rantai yang panjang bertujuan untuk menghapus atau mengurangi akibat-akibat yang merugikan terhadap lingkungan hidup, mata rantai tersebut yaitu: (1) Penentuan kebijaksanaan, desain dan perencanaan, pernyataan dampak lingkungan; (2) Peraturan tentang standar atau pedoman minimum prosedur perizinan; (3) Keputusan administratif terhadap pelanggaran, penentuan tenggang waktu dan hari terakhir agar peraturan diataati; (4) Gugatan perdata untuk mencegah atau menghambat pelanggaran pemberian denda atau ganti rugi; (5) Gugatan masyarakat untuk memaksa atau mendesak pemerintah untuk mengambil tindakan gugatan ganti rugi; (6) Tuntutan pidana.

Penegakan hukum lingkungan dengan instrumen pidana sangat penting dalam mengantisipasi perusakan dan pencemaran lingkungan (Supriadi, 2016; Rahmadi, 2011). Banyak orang mengatakan instrumen hukum pidana sebagai ultimum remedium atau senjata pamungkas yang paling dahsyat dan mampu menuntaskan masalah penyakit kriminalitas secara total dan tuntas. Suatu ancaman pidana tidak akan berarti apa-apa tanpa disertai penegakan hukum atas pelanggarannya, oleh sebab itu melaksanakan ketentuan pidana bukan lagi hendaknya sebagai ultimum remedium akan tetapi hendaknya hukum pidana digunakan sebagai premium remedium. 
Hal ini juga didukung oleh salah satu Jaksa dari Kejaksanaan Negeri Sidoarjo Laysa Agastya Niratama bahwa perlunya tindakan tegas terkait Korporasi melihat adanya dampak Lingkungan Hidup dari perbuatan yang dilakukannya. Karena apa yang telah dilakukan korporasi telah menyebabkan kerusakan lingkungan yang parah (Muladi \& Dwidja, 2012).

UUPLH mengatur banyak pasal tentang sanksi pidana, mulai dari Pasal 97 sampai dengan Pasal 120. Dalam hal ini tidak dibedakan kualifikasi perbuatan pidana karena alpa/lalai dengan sengaja. Kesemua perbuatan yang mencemarkan dan merusak lingkungan hidup disebut dengan kejahatan lingkungan. Ancaman yang diberikan terhadap pelaku pelanggaran hukum lingkungan yakni berupa pidana penjara dan denda (Moeljatno, 2002).

Kajian teoritik hukum pidana, tindak (perbuatan) pidana dapat dibedakan atas delik materil dan delik formil. Delik materil dapat dikenai sanksi pidana dalam hal akibat dari perbuatan pidana yang dilakukan telah terjadi. Sedangkan delik formil perumusannya dititik beratkan pada perbuatan yang dilarang (Moeljatno, 2002).

Apabila dikaitkan dengan pelanggaran hukum lingkungan, maka ketentuan pidana yang dapat dikenakan adalah delik materil. Hal ini disebabkan karena, meskipun dampak dari pelanggaran atau kejahatan lingkungan baru akan dirasakan setelah bertahun- tahun kemudian, tetapi yang terpenting adalah bahwa perbuatan melawan hukum lingkungan tersebut telah dilakukan. Oleh karena itu bagi pelaku dapat dikenakan sanksi pidana.

Secara rinci, ketentuan pidana dalam UUPLH yang mengatur tentang pencemaran limbah B3, khususnya limbah Bottom Ash. Sanksi pidana terhadap pelaku pencemaran limbah bahan berbahaya dan beracun (B3) yang diatur dalam Undang-Undang Nomor 32 Tahun 2009 tentang Perlindungan dan Pengelolaan Lingkungan Hidup yaitu Pasal 102, 103, 104, 105, 106, dan 107 sebagai berikut:

Pasal 102: Setiap orang yang melakukan pengelolaan limbah B3 tanpa izin sebagaimana dimaksud dalam Pasal 59 ayat (4), dipidana dengan pidana penjara paling singkat 1 (satu) tahun dan paling lama 3 (tiga) tahun dan denda paling sedikit Rp1.000.000.000,00 (satu miliar rupiah) dan paling banyak Rp3.000.000.000,00 (tiga miliar rupiah).

Pasal 103: Setiap orang yang menghasilkan limbah B3 dan tidak melakukan pengelolaan sebagaimana dimaksud dalam Pasal 59, dipidana dengan pidana penjara paling singkat 1 (satu) tahun dan paling lama 3 (tiga) tahun dan denda paling sedikit Rp1.000.000.000,00 (satu miliar rupiah) dan paling banyak Rp3.000.000.000,00 (tiga miliar rupiah).

Pasal 104: Setiap orang yang melakukan dumping limbah dan/atau bahan ke media lingkungan hidup tanpa izin sebagaimana dimaksud dalam Pasal 60, dipidana dengan pidana penjara paling lama 3 (tiga) tahun dan denda paling banyak Rp3.000.000.000,00 (tiga miliar rupiah).

Pasal 105: Setiap orang yang memasukkan limbah ke dalam wilayah Negara Kesatuan Republik Indonesia sebagaimana dimaksud dalam Pasal 69 ayat (1) huruf c dipidana dengan pidana penjara paling singkat 4 (empat) tahun dan paling lama 12 (dua belas) tahun dan denda paling sedikit Rp 4.000.000.000,00 (empat miliar rupiah) dan paling banyak Rp12.000.000.000,00 (dua belas miliar rupiah).

Pasal 106: Setiap orang yang memasukkan limbah B3 ke dalam wilayah Negara Kesatuan Republik Indonesia sebagaimana dimaksud dalam Pasal 69 ayat (1) huruf d, dipidana dengan pidana penjara paling singkat 5 (lima) tahun dan paling lama 15 (lima belas) tahun dan denda paling sedikit Rp5.000.000.000,00 (lima miliar rupiah) dan paling banyak Rp15.000.000.000,00 (lima belas miliar rupiah).

Pasal 107: Setiap orang yang memasukkan B3 yang dilarang menurut peraturan perundang-undangan ke dalam wilayah Negara Kesatuan Republik Indonesia sebagaimana dimaksud dalam Pasal 69 ayat 
(1) huruf $b$, dipidana dengan pidana penjara paling singkat 5 (lima) tahun dan paling lama 15 (limabelas) tahun dan denda paling sedikit Rp5.000.000.000,00 (lima miliar rupiah) dan paling banyak Rp15.000.000.000,00 (lima belas miliar rupiah).

Beberapa ketentuan di atas adalah ketentuan-ketentuan yang mengatur tentang pidana bagi pelaku tindak pidana di bidang lingkungan hidup. Penegakan hukum khususnya dan penegakan hukum lingkungan khususnya suatu hal yang prinsip diterapkan adalah keadilan, sebab adil menurut satu pihak belum tentu adil menurut pihak lain. Menurut Aristoteles keadilan adalah kelayakan dalam tindakan manusia (fairness in human action). Kelayakan merupakan titik tengah diantara kedua ujung yang ekstrim yang terlalu banyak dan terlalu sedikit. Dasar teori Aristoteles adalah prinsip persamaan. Sementara itu Jeremi Bentham menyatakan tujuan hukum dalam mewujudkan keadilan adalah mewujudkan kebahagian yang sebesar besarnya untuk sebanyak- banyak orang.

Apabila tindak pidana lingkungan hidup dilakukan oleh atas nama badan usaha atau perusahaan maka tuntutan pidana dan sanksi pidana dijatuhkan kepada badan usaha atau orang yang memberi perintah untuk melakukan tindak pidana tersebut atau orang yang bertindak sebagai pemimpin kegiatan dalam tindak pidana tersebut (Pasal 116 ayat (1) dan (2) Undang-Undang Nomor 32 Tahun 2009 tentang Perlindungan dan Pengelolaan Lingkungan Hidup). Ancaman pidana sebagaimana tercantum dalam pasal- pasal UndangUndang Nomor 32 Tahun 2009 tentang Perlindungan dan Pengelolaan Lingkungan Hidup adalah pidana penjara dan denda. Selain itu ada pidana tambahan atau tindakan tata tertib terhadap badan usaha dalam Pasal 119 berupa: a) Perampasan keuntungan yang diperoleh dari tindak pidana; b) Penutupan seluruh atau sebagian tempat usaha dan / atau kegiatan; c) Perbaikan akibat tindak pidana; c) Pewajiban mengerjakan apa yang dilalaikan tanpa hak; d) Penempatan Perusahaan dibawah pengampuan paling lama 3 (tiga) tahun.

Dapat dilihat bahwa sanksi pidana denda pada beberapa kasus di atas bukan lagi dalam hitungan jutaan rupiah tetapi dinaikkan menjadi standar miliaran rupiah. Dalam undang-undang yang baru tersebut, juga diatur masalah pertanggujawaban pidana bagi korporasi, yang selanjutnya dapat dikenakan kepada yang memerintah sehingga terwujud tindak pidana pencemaran lingkungan, tanpa memerhatikan terjadinya tindak pidana itu secara bersama-sama (vide: Pasal 116 ayat 2). Pengaturan yang berbeda juga dapat diamati pada peran kejaksaan yang dapat berkoordinasi dengan instansi yang bertanggung jawab dibidang perlindungan hidup untuk melaksanakan eksekusi dalam melaksanakan pidana tambahan atau tindakan tata tertib (vide: Pasal 119 dan Pasal 120).

\section{Kendala penegakan hukum terhadap korporasi sebagai pelaku tindak pidana lingkungan hidup}

Dari beberapa hasil penelitian penulis di lapangan, ditemukan beberapa kendala dalam penegakan hukum terhadap pelaku Korporasi. Menurut salah Hakim Pengadilan Negeri Sidoarjo, beberapa kendala antara lain; a) Kekurangan sumber daya manusia yang tahu tentang perkara lingkungan; b) Perbedaan pemahaman apparat penegak hukum dalam penerapan hukum pidana lingkungan; c) Pembuktian rumit; d) Kuatnya backing perkara perusakan lingkungan; e) Pertanggung jawaban korporasi untuk mengembalikan kerugian Negara.

Kendala diatas menyebabkan sedikitnya perkara tindak pidana lingkungan yang dilakukan kooporasi sulit diajukan ke pengadilan. Selain itu, terdapat berbagai hambatan penegakan hukum terhadap korporasi sebagai pelaku tindak pidana lingkungan hidup di wilayah Hukum Sidoarjo yang mengakibatkan tidak efektivitasnya penegakan hukum lingkungan. Pemerintah sudah mengeluarkan beberapa peraturan perundang- undangan terkait penegakan hukum ini, namun pelaksanaanya dilapangan masih ditemui beberapa kendala.

Peraturan terkait dengan penegakan hukum terhadap kejahatan korporasi dalam tidak pidana lingkungan hidup antara lain adalah Undang-Undang Nomor 32 Tahun 2009 maupun peraturan pelaksana maupun peraturan pendukung yang lain, seperti PP Nomor 101 Tahun 2014 tentang Pengelolaan Limbah Bahan Berbahaya dan Beracun. Sarana hukum yang diatur meliputi sarana 
hukum administratif, sarana hukum perdata, dan sarana hukum perdata. Ketiga sarana tersebut dapat digunakan sesuai dengan kondisi yang ada. Dalam sarana hukum adminstratif, aspek pengawasan administrasi perlu dilakukan dengan ketat agar setiap pelanggaran yang dilakukan oleh korporasi bisa segera diketahui dan ditindaklanjuti. Sarana hukum administrasi ini merupakan sarana preventif agar tidak terjadi pelanggaran aturan yang lebih jauh yang bisa berubah menjadi aspek perdata maupun pidana. Dalam prakteknya, kegiatan pengawasan yang dilakukan di wilayah hukum Sidoarjo masih kurang karena kurangnya SDM yang bertugas untuk melakukan pengawasan terhadap kepatuhan perusahaan akan aturan terkait lingkungan hidup di wilayah hukum Sidoarjo. (Wawancara dengan salah satu Hakim di PN. Sidoarjo dan Jaksa pada kejaksaan Negeri Sidoarjo).

Aparat penegak hukum merupakan salah satu elemen yang sangat menentukan proses penegakan hukum terhadap korporasi yang melakukan kejahatan lingkungan hidup. Aparat penegak hukum yang terkait dengan penegakan hukum lingkungan ini meliputi: pertama, pejabat yang berwenang memberi ijin, kedua, polisi, ketiga, jaksa, keempat, hakim, kelima, pengacara/konsultan hukum (Waluyo, 1999). Banyak kasus-kasus kejahatan korporasi di wilayah hukum Sidoarjo terkendala dikarenakan jumlah aparat penegak hukum profesional yang mampu menangani kasus-kasus lingkungan masih sangat terbatas. Disamping itu masalah lingkungan hidup mencakup aspek yang sangat luas dan kompleks yang berkenaan dengan berbagai disiplin ilmu. Keterbatasan pengetahuan dan pemahaman aspekaspek lingkungan oleh penegak hukum menjadi faktor kendala yang sangat dominan dalam upaya untuk menciptakan kesamaan presepsi penanganan perkara lingkungan. Sementara itu cukup sulit untuk mendapatkan aparat penegak hukum yang menguasai berbagai macam pengetahuan terkait dengan lingkungan.

Faktor fasilitas dan sarana merupakan salah satu alat untuk mencapai tujuan penegakan hukum lingkungan. Ketiadaan atau keterbatasan fasilitas dan sarana penunjang akan sangat mempengaruhi keberhasilan penegakan hukum lingkungan. Bahwa kenyataan menunjukan dalam penanganan kasuskasus lingkungan akan melibatkan berbagai perangkat berteknologi canggih, seperti alat pendeteksi pencemaran maupun alat-alat di laboratorium yang operasionalisasinya membutuhkan tenaga yang ahli dan memerlukan dana yang tidak sedikit untuk penggunaan alat-alat tersebut.

Keberadaan korporasi merupakan satu hal yang tidak bisa dihindari. Korporasi merupakan salah satu entitas bisnis yang diperlukan dalam pembangunan dan perekonomian di Indonesia. Salah satu tanda negara maju atau berkembang adalah kegiatan korporasi yang mengalami peningkatan. Keberadaan korporasi juga akan memberikan nilai tambah secara ekonomi kepada pemerintah daerah setempat maupun kepada pemerintah pusat. Oleh karena itulah maka pemerintah, baik pemerintah pusat maupun pemerintah daerah selalu memberikan dorongan dan kemudahan bagi munculnya industri baru dan pengembangan indusrti yang sudah ada. Oleh karena itulah maka diberikan kemudahan oleh Pemerintah Sidoarjo untuk perizinan bagi usaha baru ataupun perizinan untuk pengembangan usaha yang sudah ada.

Pada sisi yang lain, keberadaan korporasi merupakan ancaman terhadap kondisi lingkungan hidup ketika korporasi tidak beraktivitas sesuai dengan aturan yang ada, seperti terkait pengelolaan sampah dan Limbah B3 nya. Dalam kondisi ini diperlukan pegawasan yang ketat terhadap setiap korporasi yang ada, akan tetapi karena SDM pengawas terbatas sehingga banyak terjadi pelanggaran aturan lingkungan hidup oleh korporasi yang ada.

Sistem Analisis Mengenai Dampak Lingkungan (AMDAL) merupakan salah satu persyaratan administasi yang harus dipenuhi oleh sebuah korporasi ketika akan melakukan aktivitas usaha terkait dengan lingkungan. Dalam prakteknya, AMDAL lebih mengarah pada penonjolan pemenuhan ketentuan administratif daripada subtantifnya. Artinya pesatnya permintaan akan AMDAL merupakan mata rantai kewajiban dalam urusan perizinan dalam suatu usaha atau dipandang sebagai performa untuk mendapatkan akad kredit atau izin investasi. Proses transparansi dan mekanisme keterbukaan dokumen AMDAL bagi masyarakat tidak berjalan sesuai harapan, bahkan masyarakat (yang terkena dampak) tidak mengetahui secara pasti adanya suatu aktifitas kegiatan. 
Setelah korporasi menyelesaikan AMDAL dan juga memperoleh ijin usaha serta menjalankan proses produksinya, sering kali korporasi tidak memperhatikan kodisi lingkungan sehingga ketentuanketentuan yang semula sudah dapat dipenuhi dalam dokumen AMDAL, dalam prakteknnya tidak bisa dipenuhi. Dalam kondisi seperti tentunya aparat penegak hukum yang perlu melakukan upaya aktif, yaitu melakukan pengawasan terhadap semua kegiatan perusahaan yang ada dan melakukan penegakan hukum ketika ada aturan dalam AMDAL yang dilanggar. Keterbatasan SDM sekali menjadi masalah dalam penegakan hukum AMDAL di wilayah Hukum Sidoarjo.

Masyarakat merupakan salah satu komponen penting dalam penegakan hukum lingkungan yang setiap hari berinteraksi dengan lingkungan sehingga mereka mengetahui kondisi lingkungan. Salah satu skema dalam penegakan hukum adalah adanya masukan atau informasi dari masyarakat tentang sebuah pelanggaran aturan lingkungan hidup oleh sebuah korporasi. Saat ini belum semua masyarakat mengetahui aturan hukum lingkungan yang mengikat kegiatan korporasi sehingga ketika terjadi pelanggaran masyarakat tidak mengetahui. Terkadang ada juga masyarakat yang mengetahui sebuah pelanggaran hukum/ aturan hukum lingkungan oleh sebuah korporasi, akan tetapi karena kesadaran hukum masyarakat masih rendah sehingga mereka tidak acuh terhadap kondisi tersebut dan tidak melaporkannya kepada pihak yang berwajib.

\section{Simpulan}

Penegakan hukum lingkungan dilakukan melalui upaya represif, yaitu melalui jalur hukum penegakan pidana mulai penyelidikan sampai kepada putusan pengadilan. Kasus yang dibahas melibatkan korporasi, sehingga sesuai dengan Pasal 116 ayat (1) dan (2) UndangUndang Nomor 32 Tahun 2009 tuntutan pidana dan sanksi pidana dijatuhkan kepada badan usaha atau orang yang memberi perintah untuk melakukan tindak pidana tersebut atau orang yang bertindak sebagai pemimpin kegiatan dalam tindak pidana tersebut. Terdapat beberapa hal yang menjadi kendala dalam penegakan hukum atas korporasi yang melakukan kejahatan atas lingkungan hidup di wilayah Sidoarjo, antara lain adalah sarana hukum, aparat penegak hukum, fasilitas dan sarana, perizinan, sistem Analisi mengenai dampak lingkungan (AMDAL), dan kurangnya keikutsertaran masyarakat.

Upaya yang bisa dilakukan terhadap untuk mengatasi kendala penegakan hukum terhadap kejahatan korporasi terhadap lingkungan di Sidoarjo diperlukan penyuluhan yang intensif kepada masyarakat yang dapat dilakukan oleh pihak terkait, seperti Dinas Lingkungan Hidup dan Kebersihan Kabupaten Sidoarjo maupun oleh aparat Kepolisian yang membidangi masalah Lingkungan; menambah jumlah aparat penegak hukum; Meningkatan pengawasan pasca pemberian ijin; meningkatkan fungsi AMDAL sebagai alat penegakan hukum lingkungan; dan memberikan pelatihan/ training kepada aparat penegak hukum yang konsentrasinya pada hukum lingkungan.

\section{Daftar Pustaka}

Hamzah A (2001) Asas-Asas Hukum Pidana. Jakarta: Rineka Cipta.

Waluyo B (1999) Penelitian Hukum dalam Praktek. Jakarta: Sinar Grafika.

Arief BN (2002) Kebijakan Hukum Pidana. Bandung: PT. Citra Aditya Bakti.

Moleong LJ (2012) Metode Penelitian Kualitatif. Bandung: Remaja Rosdakarya.

Arifin S (2012) Hukum Perlindungan dan Pengelolaan Lingkungan Hidup di Indonesia. Jakarta: PT. Soft Media.

Cho BS (2000) Emergence of an international environmental criminal law? UCLA Journal of Environmental Law and Policy 19 (1):11-47.

Cohen MA (1992) Environmental crime and punishment: Legal/ economic theory and empirical evidence on enforcement of federal environmental statutes. Journal of Criminal Law and Criminology 82 (4):1053 - 1108.

Barret S \& White R (2017) Disrupting environmental crime at the local level: An operational perspective. Palgrave Communications 3 (2):32 - 43. 
Greife M, Stretesky PB, Shelley TO \& Pogrebin M (2015). Corporate Environmental Crime and Environmental Justice 28 (4):327-346.

Moeljatno (2002) Perbuatan Pidana dan Pertanggungjawaban Dalam Hukum Pidana. Yogyakarta: Bina Aksara.

Muladi \& Dwidja P (2012) Pertanggungjawaban Pidana Korporasi. Jakarta: Kencana Prenada Media Group.

Supriadi (2006) Hukum Lingkungan Di Indonesia Sebuah Pengantar. Jakarta: Sinar Grafika.

Shover N \& Routhe (2005) Environmental crime. Crime and Justice 32:321-371.

Rahmadi T (2011) Hukum Lingkungan di Indonesia. Jakarta: PT. Raja Grafindo Persada.

Rosman A \& Isa SM (2014) Corporate responbility for enviromental human rights violence: A case study of Indonesia. Pertanika Journal Social Science \& Humanity 22 (s):111 - 130. 